\title{
Rekayasa Produksi Biodiesel Dari Minyak Kemiri Sunan (Reutialis Trisperma Oil) Sebagai Alternatif Bahan Bakar Mesin Diesel
}

\author{
Susanti Dhini Anggraini ${ }^{(1)}$ \\ ${ }^{(1)}$ Jurusan Teknik Industri, Fakultas Teknik, Universitas PGRI Ronggolawe Tuban \\ Email: susantidhini@gmail.com ${ }^{(1)}$
}

\begin{abstract}
Abstrak
Pada penelitian ini, biodiesel diproduksi dari new feedstock minyak Kemiri Sunan. Minyak Kemiri Sunan merupakan minyak non edible sehingga sangat menarik untuk diproduksi sebagai biodiesel. Minyak Kemiri sunan diproduksi dengan dua tahapan reaksi yaitu reaksi esterifikasi dan transesterifikasi menggunakan katalis $\mathrm{H}_{2} \mathrm{SO}_{4}$ dan $\mathrm{KOH}$. Reaksi esterifikasi telah dilakukan perbandingan minyak:metanol (3:1) selama 2 jam. Reaksi transesterifikasi dilakukan dengan variasi konsentrasi katalis $\mathrm{KOH}(0,5$; 1,$0 ; 1,5 ; 2,0 \%$ berat minyak), rasio minyak:metanol $(1: 1 ; 2: 1 ; 3: 1$ (berat/berat)), dan suhu reaksi 65 selama 1 jam. Yield dan sifat biodiesel dianalisis dengan Chromatography Gas (GC) dan ASTM D 6751. Yield optimum biodiesel diperoleh sebesar 96,91\%, pada kondisi optimum konsentrasi katalis $\mathrm{KOH} 1 \%$ berat minyak, rasio minyak:metanol 1:1 (berat/berat) dan suhu reaksi $65{ }_{\circ} \mathrm{C}$. Biodiesel berbahan dasar minyak kemiri sunan mempunyai rentang angka asam 0,41-0,56 $\mathrm{mgKOH} / \mathrm{gram}$, densitas $0,89-0,91 \mathrm{gram} / \mathrm{cm}_{3}$, viscositas 8,28-12,70 cSt, angka setana 58,2-63,3 dan residu karbon 0,23-0,59 \%berat/berat.
\end{abstract}

Kata Kunci: Minyak kemiri sunan (Reutealis trisperma Oil), yield biodiesel, $\mathrm{KOH}$.

\begin{abstract}
In this research, biodiesel was produced from new feedstock Kemiri Sunan oil. Kemiri Sunan oil is non edible oil, an attractive raw material for production of biodiesel. Biodiesel was produced by two steps of reactions, i.e. esterification and transesterification, using $\mathrm{H}_{2} \mathrm{SO}_{4}$ and $\mathrm{KOH}$ as catalyst, respectively. Esterification reaction was carried out with methanol for $2 \mathrm{~h}$, ratio oil:methanol (3:1). Transesterification was done at various catalyst concentration $(0.5 ; 1.0 ; 1.5 ; 2.0 \% \mathrm{wt}$ oil), ratio oli:methanol $(1: 1,2: 1,3: 1(\mathrm{wt} / \mathrm{wt}))$, and reaction temperature $(30,50,65$, $70 . \mathrm{C}$ ) for $1 \mathrm{~h}$. The yield and properties of biodiesel were analysed by Gas Chromatography (GC) and ASTM D 6751 methods, respectively. High yield of biodiesel was produced at $\mathrm{KOH} 1 \% \mathrm{wt}$ catalyst, ratio methanol:oil $(1: 1)$ and $65 \mathrm{oC}$ i.e. $96,91 \%$. Kemiri Sunan oil-based biodiesel had a range of acid number 0,41-0,56 $(\mathrm{mgKOH} / \mathrm{g})$, densitas $0,89-0,91\left(\mathrm{~g} / \mathrm{cm}_{3}\right)$, viscosity 8,28-12,70 $(\mathrm{cSt})$, cetane number $58,2-63,3$, and residu carbon $0,23-0,59.1$
\end{abstract}

Keyword : Kemiri sunan Oil (Reutealis trisperma Oil), yield biodiesel, KOH. 


\section{Pendahuluan}

Dewasa ini krisis energi dunia semakin meningkat hal ini disebabkan semakin menipisnya cadangan bahan bakar fosil. Oleh karena itu sekarang ini dikembangkan bahan bakar alternatif yaitu biodiesel [1],[2],[3]. Salah satu minyak nabati yang banyak terdapat di Indonesia dan bersifat non edible adalah minyak kemiri sunan. Daging biji kemiri sunan mengandung minyak 52\% atau $40 \%$ dari biji/gelondong. Kemiri sunan termasuk salah satu tanaman yang benilai ekonomi baik dan bersifat multiguna. Salah satu keunggulan dari kemiri sunan merupakan bahan non edible, sehingga tidak menyebabkan kesenjangan dengan bahan makanan. Kemiri sunan memiliki kandungan minyak yang tinggi, karakteristik minyak yang khas sehingga dapat dimanfaatkan untuk berbagai keperluan, pertumbuhannya relatif cepat, wilayah pengembangannya luas dari dataran rendah hingga $1.000 \mathrm{~m}$ diatas permukaan laut, dan sangat cocok sebagai tanaman konservasi. Minyak kemiri sunan belum banyak diperdagangkan sehingga kemiri sunan merupakan salah satu alternatif bahan dasar biodiesel yang perlu diteliti.

Biodiesel dihasilkan dari minyak tumbuhan atau lemak hewan melalui reaksi esterifikasi dari asam lemak bebas dengan alkohol melalui katalis asam atau transesterifikasi dari trigliserida dengan alkohol melalui katalis basa [4],[5],[6]. Katalis adalah suatu zat yang dapat mempercepat reaksi dengan menurunkan energi aktivasi reaksi. Metode paling umum untuk menghasilkan biodiesel adalah melalui proses transesterifikasi dengan menggunakan katalis homogen basa kuat seperti $\mathrm{NaOH}$ dan $\mathrm{KOH}$. Penggunaan katalis homogen ini banyak keuntungan yaitu reaksi pembentukan biodiesel lebih cepat dan yield biodieselnya besar, akan tetapi penggunaaan katalis homogen ini dapat menghasilkan sabun (saponifikasi) pada saat reaksi dan pencucian biodiesel [7],[6],[8]. Katalis basa homogen yang umumnya digunakan untuk sintesis biodiesel menggunakan reaksi transesterifikasi minyak nabati yaitu logam alkali ( $\mathrm{Na}$ dan $\mathrm{K}$ ) hidroksida [9], [10]. Transesterifikasi feedstock minyak nabati banyak menggunakan katalis homogen $\mathrm{KOH}$, misalnya Li dkk (2012) melaporkan sintesis minyak kedelai dengan katalis KOH dapat menghasilkan yield biodiesel 96\% dan Encinar dkk (2012) juga melaporkan sintesis minyak rapeseed menggunakan katalis $\mathrm{KOH}$ menghasilkan yield biodiesel $95 \%$.

Ada beberapa parameter untuk mengoptimasi yield biodiesel salah satunya adalah variasi konsentrasi katalis, variasi rasio metanol:minyak dengan dan variasi suhu reaksi. Menurut [11], [12] melakukan sintesis biodiesel dari limbah minyak goreng dengan variasi konsentrasi katalis $\mathrm{KOH}$, pada konsentrasi tertentu diperoleh yield optimum dan semakin tinggi konsentrasi katalis terjadi penurunan jumlah yield karena terjadi reaksi penyabunan. Adanya sabun ini sangat tidak menguntungkan untuk proses sintesis biodiesel, oleh karena itu perlu dilakukan reaksi esterifikasi untuk mengurangi nilai FFA (Free Fatty Acid) dan variasi konsentrasi katalis untuk mencapai yield yang maksimal. Penurunan nilai FFA dapat dilakukan dengan reaksi esterifikasi yaitu minyak dengan alkohol (metanol) menggunakan katalis asam $\mathrm{H} 2 \mathrm{SO} 4$, hal ini dapat memperkecil nilai angkA asam sehingga mengurangi efek penyabunan untuk reaksi transesterifikasi [13].

Pada penelitian ini akan dilakukan rekayasa sintesis biodiesel dengan bahan dasar minyak kemiri sunan dengan mengunakan katalis basa homogen yaitu $\mathrm{KOH}$ dan dipelajari pengaruh variasi konsentrasi katalis $\mathrm{KOH}$, variasi rasio minyak dengan metanol dan variasi suhu tersebut terhadap yield biodieselnya. Biodiesel hasil sintesis dari minyak kemiri sunan akan diamati pula karakteristiknya dan dibandingkan dengan standar biodiesel ASTM D 6751-02 dan SNI.

\section{Metode Penelitian}

Peralatan yang digunakan pada penelitian ini adalah peralatan-peralatan gelas, seperangkat peralatan refluks untuk reaksi esterifikasi dan transesterifikasi, pengaduk magnetik (stirer), oven listrik, neraca analitik untuk penimbangan sampel, kondensor refluks, piknometer, Kinematika Viscometer Bath untuk analisis viskositas, Octane meter untuk analisis angka setana, Chromatography Gas (GC) (techcomp 7900) untuk pengujian hasil biodiesel.

Bahan-bahan yang digunakan pada penelitian ini adalah Minyak kemiri sunan yang di suplay dari PT. KEMIRI SUNAN, KOH (Merck, 99\%), KOH (merck, 99\%) sebagai katalis pada reaksi 
transesterifikasi, metanol (Merck, 99\%), n-heksana (Merck, 99\%), H2SO4 (Merck, 98\%) sebagai katalis dalam reaksi esterifikasi, etanol (Merck 99\%), phenolphtalein (Merck, 99\%), asam oksalat (Merck, 99\%), metil palmitat (Merck, 99\%), metil oleat (Merck, 99\%), metil stearat (Merck, 99\%), metil heptadekanoat (Merck, 99\%) sebagai standart internal dan akuades.

\subsection{Prosedur Penelitian}

\section{Esterifikasi Asam Lemak Bebas Minyak Kemiri Sunan}

Minyak kemiri sunan dengan kandungan FFA 2,44\% dapat diturunkan angka asamnya dengan reaksi esterifikasi menggunakan metanol dan katalis asam sulfat. Reaksi esterifikasi dilakukan dengan perbandingan rasio metanol:minyak 1:3 (berat/berat) dengan penambahan katalis asam sulfat 3 \% berat minyak. Reaksi esterifikasi terbentuk dua lapisan yaitu lapisan atas yang terdiri dari metanol sisa dan air sedangkan lapisan bawah yaitu minyak kemiri sunan hasil reaksi esterifikasi (RETROE). (RETROE) dipisahkan dengan corong pisah dan dilanjutkan dengan reaksi transesterifikasi

\section{Transesterifikasi Minyak Kemiri Sunan Hasil Reaksi Esterifikasi}

Minyak kemiri sunan hasil reaksi esterifikasi (RETROЕ) dilakukan reaksi transeterifikasi dengan menggunakan metanol dan katalis basa kalium hidroksida $(\mathrm{KOH})$. Reaksi transesterifikasi dilakukan dengan perbandingan rasio minyak:metanol 2:1 (berat/berat) dengan penambahan katalis $\mathrm{KOH} 1 \%$ berat minyak. Reaksi dilakukan dengan kondisi suhu $65^{\circ} \mathrm{C}$ selama 1 jam. Hasil akhir reaksi transesterifikasi terbentuk dua lapisan yang terpisah yaitu bagian bawah metil ester (biodiesel) sedangkan bagian atas adalah sisa metanol dan gliserol. Lapisan yang berupa metil ester di cuci dengan etanol dan air sampai jernih. Pada tahap pencuci terbentuk dua fasa yaitu fasa bagian bawah metil ester sedangkan fasa bagian atas etanol dan air (Prasetyoko dan oetami, 2012). Reaksi transesterifikasi dilakukan dengan variasi katalis $(0,5 ; 1,0 ; 1,5 ; 2,0 \%$ berat $)$, variasi minyak: metanol $(1: 1 ; 2: 1 ; 3: 1$ berat/berat) dan variasi suhu $\left(30,50,65,70^{\circ} \mathrm{C}\right)$. Hasil reaksi transesterifikasi dihitung nilai yield metil esternya.

\section{Analisis Gas Chromatography (GC)}

Biodiesel hasil produksi dengan variasi katalis $\mathrm{KOH}$, rasio metanol:minyak dan suhu reaksi dianalisis dengan alat Kromatografi Gas. Kromatografi gas ini digunakan untuk mengetahui konsentrasi metil ester yang terkandung dalam biodiesel. Yield biodiesel dari minyak kemiri sunan dapat ditentukan dengan Persamaan 1 (Yang dkk., 2011). Gas Chromatography (GC) 7600 jenis detektor yang digunakan adalah Flame Ionization Detector (FID), kolom kapiler yang berjenis nonpolar EC-TM5-(5\% phenyl)-methyl polixinoxane dengan panjang kolom: 30m diameter kolom (id): $0,25 \mathrm{~m}$ dan film thickness: $0,25 \mu \mathrm{m}$. Kondisi operasi yang digunakan dengan suhu oven $200^{\circ} \mathrm{C}(2 \mathrm{menit})\left(5^{\circ} \mathrm{C} / \mathrm{menit}\right.$ $220^{\circ} \mathrm{C}$, 2menit) $\left(4^{\circ} \mathrm{C} /\right.$ menit $250^{\circ} \mathrm{C}$ menit) suhu inlet $250^{\circ} \mathrm{C}$, suhu detector $250^{\circ} \mathrm{C}$, running 17 menit. Biodiesel sebanyak $70 \mathrm{mg}$ dilarutkan dalam $1 \mathrm{ml}$ n-heksana, lalu disuntikkan pada GC dengan microlitersyring.

Keterangan :

$$
\text { Yield }=\frac{\frac{w b}{c i}}{w a} \cdot C \cdot 100 \%
$$

$\mathrm{Wb}=$ berat biodiesel hasil reaksi (gram),

$\mathrm{Ci}=$ Konsentrasi biodiesel yang diinjekan (ppm),
$\mathrm{Wa}=$ berat minyak sebelum reaksi (gram)

$\mathrm{C}=$ Konsentrasi biodiesel (ppm)

\section{Angka asam (Acid Number)}

Angka asam dapat diperoleh dari minyak nabati murni dalam pelarut organik tertentu (alkohol 95\% netral) dengan penitraan dengan basa $(\mathrm{NaOH}$ atau $\mathrm{KOH})$. Analisis angka asam dilakukan dengan metode titrasi sesuai dengan ASTM D 664

\section{Densitas}

Analisis densitas menggunakan alat piknometer dengan metode ASTM D-4052.

Viskositas

Viskositas biodiesel diukur dengan alat Kinematic Viscometer Bath metode ASTM D-445. 


\author{
Angka Setana (Cetane Number) \\ Analisis nilai angka setane ditentukan dengan alat octane meter sesuai ASTM D-613. \\ Residu Karbon \\ Massa residu karbon biodiesel dapat dianalisis dengan metode ASTM D-4530
}

\title{
Hasil dan Pembahasan
}

Pada penelitian ini, produksi biodiesel dari minyak kemiri sunan (Reautealis trisperma oil) dengan menggunakan katalis KOH. Produksi biodiesel dari minyak kemiri sunan dilakukan dengan dua tahap reaksi yaitu esterifikasi dan transesterifikasi. Reaksi esterifikasi dilakukan dengan mereaksikan minyak dan metanol menggunakan katalis asam sulfat, dilanjutkan dengan reaksi transesterifikasi menggunakan katalis basa $\mathrm{KOH}$. Pada reaksi transesterifikasi dilakukan variasi konsentrasi katalis $(0,5 ; 1,0 ; 1,5 ; 2,0 \%$ berat), variasi rasio berat minyak:metanol $\left(1: 1 ; 2: 1 ; 3: 1\right.$ berat/berat) dan variasi suhu $\left(30 ; 50 ; 65 ; 70^{\circ} \mathrm{C}\right)$ untuk memperoleh yield optimum. Biodiesel hasil transesterifikasi dicuci, ditimbang dan dianalisis dengan gas kromatografi untuk menentukan yield biodiesel. Selanjutnya, hasil biodiesel tersebut dilakukan beberapa karakterisasi, yaitu angka asam, densitas, viskositas, angka setana dan residu karbon. Hasil karakterisasi biodiesel dibandingkan dengan standart ASTM D6751-02 dan SNI 04-7182.

\section{Reaksi Esterifikasi Asam Lemak Bebas Minyak Kemiri}

Reaksi esterifikasi pada produksi biodiesel dilakukan untuk mengurangi nilai Free Fatty Acid (FFA) dari minyak dengan meminimalkan terbentuknya sabun pada reaksi transesterifikasi (Yingying dkk., 2012). Reaksi esterifikasi merupakan reaksi antara asam lemak bebas dengan alkohol menggunakan katalis asam. Hasil reaksi esterifikasi terdiri dari dua lapisan, yaitu lapisan bawah yang merupakan trigliserida dan produk hasil reaksi esterifikasi sedangkan lapisan atas berupa metanol sisa yang tidak bereaksi dan $\mathrm{H}_{2} \mathrm{O}$. Lapisan bawah yang berupa trigliserida dan hasil esterifikasi dipisahkan dari lapisan atas dengan corong pisah. Hasil reaksi esterifikasi tersebut ditentukan kandungan FFA, dan diperoleh kandungannya sebesar $0,08 \%$. Pada penelitian ini, didapati bahwa reaksi esterifikasi dapat mengkonversi FFA minyak kemiri sunan sebesar 96,43\%. Marchetti dan Errazu (2008) melaporkan hal yang serupa yaitu reaksi esterifikasi dengan katalis $\mathrm{H}_{2} \mathrm{SO}_{4}$ dapat mengkonversi nilai FFAdari trigliserida sebesar 96\%. Pada penelitian ini lapisan bawah hasil reaksi esterifikasi dengan kandungan FFA $<1 \%$ dilanjutkan ke tahap reaksi selanjutnya yaitu transesterifikasi.

\section{Reaksi Transesterifikasi Minyak Kemiri Sunan}

Pada penelitian ini minyak hasil pemisahan dari reaksi esterifikasi yang mengandung nilai FFA 0,08\% dilanjutkan ke tahap reaksi transesterifikasi dengan menggunakan katalis basa kalium hidroksida dan metanol selama 1 jam. Hasil reaksi transesterifikasi menunjukkan dua lapisan yaitu lapisan polar dan non polar sebagaimana ditunjukkan pada Gambar 1 Lapisan polar dimungkinkan berupa metanol sisa,gliserol, hasil samping reaksidan sisa katalis $\mathrm{KOH}$. Lapisan non polar dimungkinkankandungan utama biodiesel, sisa minyak kemiri sunan yang tidak bereaksi,serta senyawa polar yang mungkin juga ada misalnya metanol, gliserol dan katalis. Lapisan bawah yang merupakan biodiesel dicuci. Pencuciannya dilakukan dengan penambahan etanol dan air panas berulang kali sampai biodiesel berwarna kuning. Etanol untuk menghilangkan sisa katalis $(\mathrm{KOH})$ sedangkan air untuk menetralkan $\mathrm{pH}$ biodiesel. Biodiesel yang telah dicuci dipanaskan untuk menghilangkan sisa air. Biodiesel yang sudah jernih ditimbang untuk menentukan yield yang dihasilkan dari biodiesel [14]. 

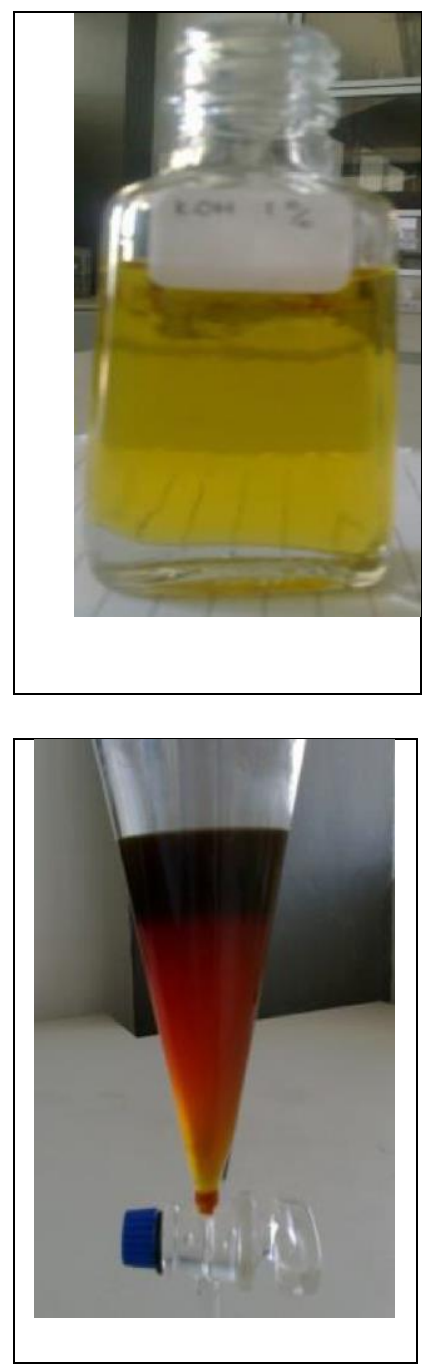

c. Biodesel hasil

a. Lapisan Polar pencucian

b. Lapisan Nonpolar

Gambar 1. Hasil reaksi transesterifikasi minyak kemiri sunan dengan dua lapisan yaitu (a) Lapisan polar, (b) Lapisan non polar dan (c) hasil pencucian

Pada reaksi transesterifikasi, kondisi reaksi sangat penting untuk mendapatkan yield yang optimum. Xu dan Hanna (2009) melaporkan bahwa biodiesel dapat dihasilkan dari minyak biji kedelai dengan 
reaksi transesterifikasi selama 80 menit, suhu reaksi $65^{\circ} \mathrm{C}$, dan konsentrasi katalis $0,7 \%$ berat minyak menghasilkan yield optimum 99\%. Optimasi dilakukan pada reaksi transesterifikasi menggunakan variasi konsentrasi katalis basa homogen $(\mathrm{KOH}$ dan $\mathrm{NaOH})(0,1-0,9 \%$ berat $)$, suhu $\left(25-85^{\circ} \mathrm{C}\right)$ dan metanol. Oleh karena itu, pada penelitian ini dilakukan beberapa variasi konsentrasi katalis, rasio berat minyak dengan metanol dan suhu reaksi pada reaksi transesterifikasi.

\section{Penentuan Jenis Metil Ester Biodiesel Minyak Kemiri Sunan}

Biodiesel yang diproduksi melalui proses esterifikasi dan transesterifikasi ditentukan jenis metil esternya dengan analisis secara kualitatif menggunakan teknik Gas Chromatography (GC). Selain itu, GC juga digunakan untuk analisis kuantitafif untuk menentukan konsentrasi metil ester dengan menambahkan internal standart metil heptadekanoat.

\section{Analisis Kualitatif Jenis Metil Ester}

Biodiesel yang diproduksi dari minyak kemiri sunan dianalisis jenis metil esternya dengan instrumen Gas Kromatografi (GC). Jenis meti ester biodiesel dapat diketahui dari waktu retensi biodiesel yang dibandingkan dengan waktu retensi larutan standart. Larutan standart yang digunakan pada penelitian ini antara lain metil palmitat, metil stearat, dan metil oleat. Pada Gambar 2 (a), (b), (c) menunjukkan kromatogram larutan standart untuk metil palmitat muncul disekitar menit ke-3,7, metil oleat disekitar menit ke-5,6, dan metil stearat disekitar menit ke-5,8.

Gambar 2 (e) menunjukkan contoh kromatogram biodiesel yang dihasilkan pada kondisi reaksi transesterifikasi dengan konsentrasi katalis $\mathrm{KOH} \mathrm{1 \%} \mathrm{berat,} \mathrm{rasio} \mathrm{berat} \mathrm{minyak:metanol} \mathrm{1:1} \mathrm{dan} \mathrm{suhu}$ reaksi $65 \circ \mathrm{C}$. Waktu retansi kromatogram biodiesel dibandingkan dengan waktu retensi larutan standart menunjukkan biodiesel minyak kemiri sunan mengandung beberapa metil ester. Kromatogram metil ester biodiesel minyak kemiri sunan untuk metil palmitat muncul pada menit ke- 3,7 menit, metil oleat muncul pada menit ke- 5,6, dan metil stearat muncul pada menit ke 5,8. Analisis gas kromatografi diatas menunjukkan bahwa biodiesel dari minyak kemiri sunan mengandung 3 metil ester antara lain metil palmitat, metil stearat danmetil oleat. Puncak pada waktu retensi 4,6 menit adalah metil heptadekanoat ditunjukkan pada Gambar 2 (d). Metil heptadekanoat digunakan sebagai standart internal pada analisis kuantitatif biodiesel. 
a)

$\bigwedge \underbrace{2}$

b)

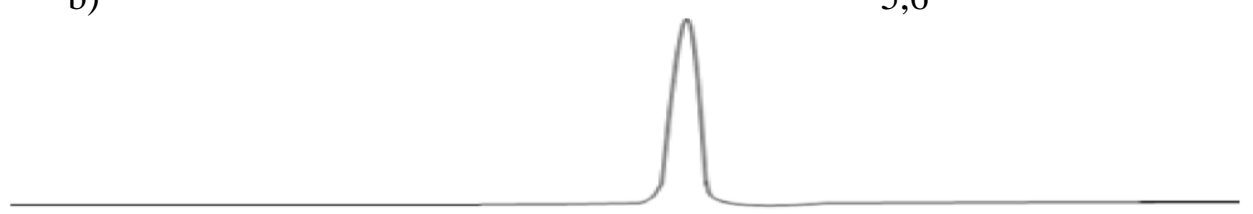

c) 4,6

d)

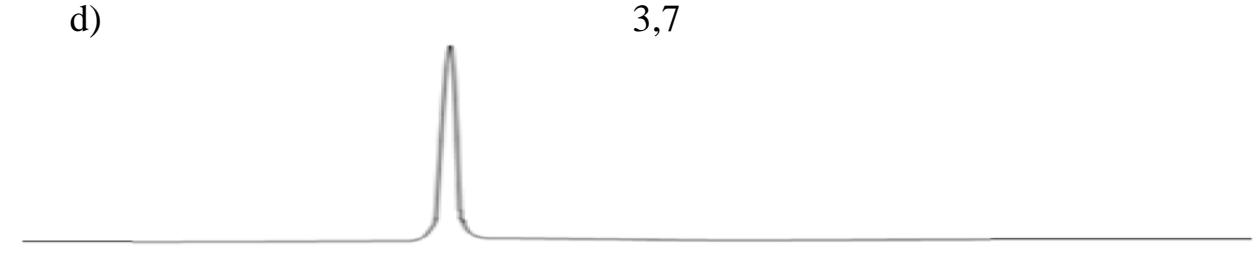

e)

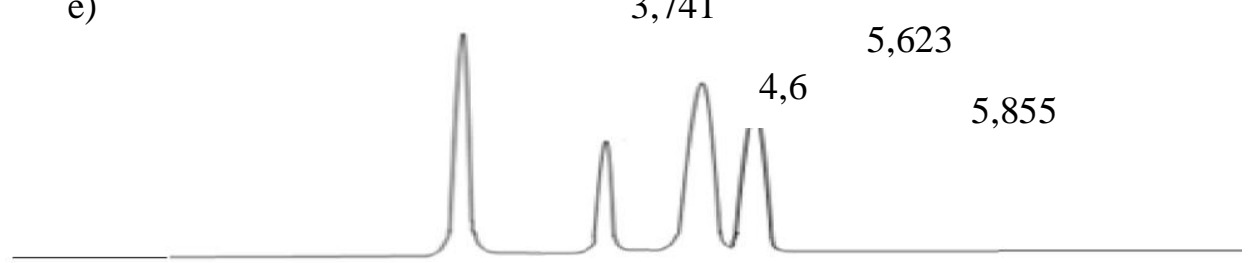

Gambar 2. Kromatogram (a) metil stearat, (b) metil oleat, (c) metil heptadekanoat, (d) metil palmitat, (e) biodiesel yang diproduksi dengan menggunakan katalis $\mathrm{KOH} 1 \%$ berat, rasio berat minyak : metanol 1:1 dan suhu reaksi $65^{\circ} \mathrm{C}$ selama 1 jam.

\section{Analisis Kuantitatif kandungan Metil Ester}

Biodiesel yang diproduksi dari minyak kemiri sunan dilakukan analisis kuantitatif dengan instrumen Gas Kromatografi (GC). Analisis kuantitatif biodiesel digunakan untuk menentukan konsentrasi metil ester [15]. Pada penelitian ini penentuan konsentrasi metil ester menggunakan standart internal metil heptadekanoat. Standart internal merupakan larutan yang ditambahkan pada sampel untuk mengurangi tingkat kesalahan dari analisis dengan instrumen GC.

Penentuan konsentrasi metil ester dilakukan dengan variasi konsentrasi larutan standart, misalnya larutan standart metil oleat. Penentuan konsentrasi metil oleat dilakukan variasi konsentrasi kemudian di analisis dengan instrument GC sehingga diperoleh luas puncak. Kurva kalibrasi metil oleat diperoleh 
dari plot hubungan antara rasio area dan konsentrasi metil oleat. Rasio area diperolah dari pembagian luas puncak dari metil oleat dengan luas puncak standart internal metil heptadekanoat. Kurva kalibrasi ini diperoleh persamaan linier untuk menentukan konsentrasi metil oleat dari biodiesel ditunjukkan pada Gambar 3.

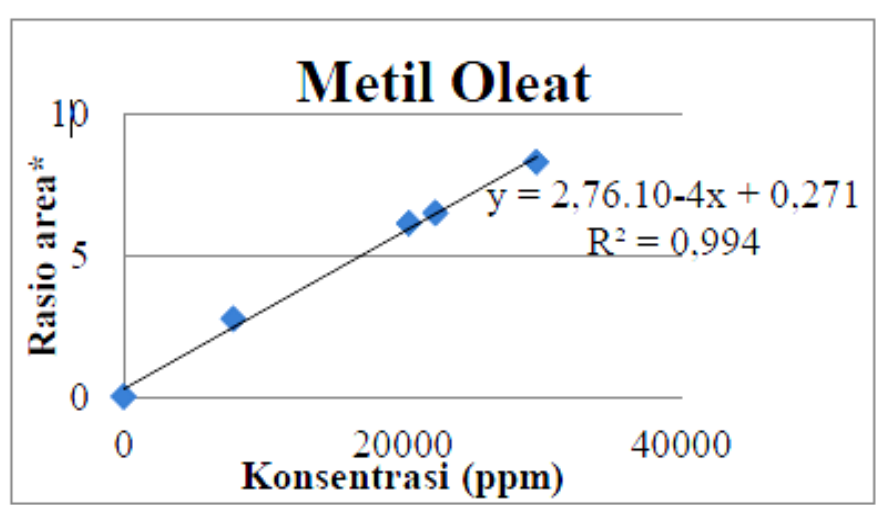

*Rasio area = area metil oleat pada biodiesel/area internal standart

Gambar 3. Kurva kalibrasi Metil Oleat

Gambar 2 (e) adalah kromatogram GC dari sampel biodiesel yang menunjukkan puncak-puncak dengan waktu retensi yang sesuai dengan metil ester eksternal standart. Metil palmitat, metil oleat, metil stearat pada sampel biodiesel diperoleh luas puncak berturut-turut 29444, 38565, 10697. Luas puncak metil ester dibagi dengan standart internal dengan luas puncak 2653, diperoleh rasio area. Rasio area metil ester dimasukkan dalam persamaan linier masing-masing larutan standart untuk menentukan konsentrasi. Konsentrasi biodiesel diperoleh dengan menjumlahkan ketiga konsentrasi metil ester tersebut. Konsentrasi biodiesel digunakan untuk menentukan yield biodiesel. Berdasarkan pada Persamaan 2, yield biodiesel diperoleh dengan mengalikan berat hasil biodiesel per berat awal minyak dengan konsentrasi metil ester yang terdapat pada biodiesel kemiri sunan (Yang dkk., 2011).

Keterangan :

$$
\text { Yield }=\frac{\frac{w b}{c i}}{w a} \cdot C \cdot 100 \%
$$

$\mathrm{Wb}=$ Berat biodiesel hasil reaksi (gram)

$\mathrm{Wa}=$ Berat minyak sebelum reaksi (gram)

$\mathrm{Ci}=$ Konsentrasi biodiesel yang disuntik ke GC (ppm)

$\mathrm{C}=$ Konsentrasi biodiesel (ppm)

Berat minyak kemiri sunan awal sebesar 30 gram. Berat biodiesel (konsentrasi katalis $\mathrm{KOH} 1 \%$ berat, rasio metanol:minyak 1:1 (berat/berat) dan suhu $65^{\circ} \mathrm{C}$ ) yang diperoleh sebesar 26,06 gram. Yield biodiesel diperoleh sebesar 96,91\%.

\section{Pengaruh Kondisi Reaksi Transesterifikasi terhadap Yield Biodiesel dari Minyak Kemiri}

Kondisi reaksi transesterifikasi memiliki peran penting untuk mendapatkan yield biodiesel yang optimum. Ada beberapa parameter yang dapat digunakan untuk mengoptimasi yield biodiesel, diantaranya adalah konsentrasi katalis, rasio metanol:minyak dan suhu reaksi [13].Oleh karena itu pada penelitian ini dilakukan beberapa variasi kondisi reaksi tersebut [16],[17].

\section{- Pengaruh Konsentrasi Katalis}

Pada reaksi transesterifiasi untuk mendapatkan yield biodiesel yang optimum dilakukan variasi konsentrasi katalis (Goodrum dan Geller, 2005). Konsentrasi katalis KOH yang dipelajari pada penelitian ini adalah 0,$5 ; 1,0 ; 1,5 ;$ dan $2,0 \%$ berat minyak. Kondisi reaksi transesterifikasi dilakukan pada suhu reaksi $65^{\circ} \mathrm{C}$ dan rasio minyak:metanol 2:1 (berat/berat) selama 1 jam. Minyak kemiri sunan 
secara visual berwarna coklat dan keruh. Hasil yang diperoleh setelah reaksi transesterifikasi dengan variasi konsentrasi katalis adalah biodiesel dengan warna kuning dan jernih [18].

Variasi konsentrasi katalis menghasilkan yield dan jumlah kandungan metil ester yang berbeda pada setiap variasinya. Yield dan kandungan metil ester pada biodiesel dengan variasi konsentrasi katalis ditunjukkan pada Tabel 1. Jumlah metil ester pada konsentrasi 0,5 dan $1 \%$ didominasi oleh metil oleat, sedangkan pada konsentrasi katalis $1,5 \%$ dan 2,0\% didominasi metil palmitat. Pada konsentrasi $1 \%$ diperoleh yield optimum biodiesel sebesar $86,92 \%$ dengan kandungan metil oleat yang besar yaitu $57,23 \%$ dibandingkan dengan metil palmitat dan stearat $27,55 \%$ dan $15,22 \%$. Berbeda halnya dengan konsentrasi $0,5 \%$ diperoleh yield biodiesel yang kecil yaitu 50,57\% dengan kandungan metil oleat $45,83 \%$. Pada konsentrasi katalis 1,5\% dan 2\% diperoleh hasil yang serupa yaitu yield biodiesel kecil dengan didominasi oleh metil palmitat sebesar 36,51\%dan 40,59\%. Giakaumis dkk (2012) melaporkan hal yang serupa kandungan metil ester dari Rice bran oil (minyak dedak padi) didominasi metil oleat 42,35\% dan metil palmitat 18,12\%.Sementara itu, Li dkk (2012) telah melaporkan juga bahwa biodiesel berbahan dasar minyak Xanthoceras sibifolia mempunyai kandungan utama yaitu metil linoleat dan metil oleat berturut-turut 41,27\% dan 29,04\%.

Pengaruh konsentrasi katalis terhadap yield biodiesel ditunjukkan pada Gambar 4. Pada konsentrasi 0,5-1,0 \%berat menunjukkan semakin tinggi konsentrasi katalis $\mathrm{KOH}$ yang digunakan untuk reaksi transesterifikasi akan menghasilkan yield biodiesel yang semakin besar. Peningkatan nilai yield biodiesel tersebut dapat dilihat pada konsentrasi 0,5 \% berat minyak diperoleh yield 50,57\% dan pada konsentrasi $1 \%$ berat minyak sebesar $86,92 \%$. Nilai yield biodiesel pada konsentrasi katalis $0,5 \%$ berat minyak nilainya lebih rendah dari pada konsentrasi $1 \%$ berat minyak. Hal ini dimungkinkan karena katalis yang digunakan untuk reaksi transesterifikasi terlalu sedikit, sehingga hanya sebagian reaktan yang bereaksi membentuk produk biodiesel (Yang dkk., 2009). Yield biodiesel berkurang setelah konsentrasi lebih dari $1 \%$ berat minyak, yang mungkin disebabkan reaksi penyabunan. Fenomena ini diamati, sulitnya pemisahan antara gliserol dengan metil ester dikarenakan meningkatnya emulsifikasi pada metil ester dan gliserol. Hasil ini sesuai dengan biodiesel yang diperoleh dari minyak sisa penggorengan menggunakan katalis basa homogen $\mathrm{KOH}$. Nilai yield biodiesel meningkat dengan meningkatnya konsentrasi katalis, dan menurun setelah konsentrasi katalis $1 \%$, yang dikarenakan biodiesel membentuk partikel sabun dan akan membentuk emulsi dengan sabun saat pencucian.

Tabel 1. Yield dan kandunganmetil ester biodieselminyak kemiri sunan yang diproduksi dengan variasi konsentrasi katalis.

\begin{tabular}{|l|c|c|c|c|c|}
\hline \multirow{2}{*}{ No } & $\begin{array}{c}\text { Konsentrasi katalis } \\
\text { KOH (\%) }\end{array}$ & \multicolumn{3}{|c|}{ Jenis metil ester (\%) } & \multirow{2}{*}{ Yield (\%) } \\
\cline { 3 - 5 } & 0.50 & Palmitat & Stearat & Oleat & \\
\hline 1. & 1.00 & 27,33 & 21,84 & 45,83 & 50.57 \\
\hline 2. & 1.50 & 36,51 & 15,22 & 57,23 & 86.92 \\
\hline 3. & 2.00 & 40,59 & 35,13 & 28,36 & 56.61 \\
\hline 4. & & 20,69 & 38,72 & 37.81 \\
\hline
\end{tabular}

(Sumber : Olah Data)

Efektifitas penggunaan katalis $\mathrm{KOH}$ pada reaksi transesterifikasi dapat diketahui dengan menghitung nilai TOF (Turn over frequency). Penentuan nilai TOF biodiesel dapat ditentukan dari perbandingan nilai mol metil ester (produk) dengan jumlah mol sisi aktif katalis per waktu reaksi. Nilai TOF yang besar menunjukkan bahwa katalis efektif untuk reaksi. Pada penelitian ini nilai TOF katalis 0,$5 ; 0,1 ; 1,5 ; 2,0 \%$ berat minyak berturut-turut 58,$30 ; 52,43 ; 15,95 ; 14,05 \%$. Pada konsentrasi $0,5 \%$ diperoleh nilai TOF yang besar menunjukkan efektifitas yang baik. Namun pada konsentrasi ini diperoleh yield yang sedikit disebabkan jumlah katalis yang digunakan pada konsentrasi ini lebih sedikit. Pada konsentrasi $1,0 \%$ nilai TOF nya lebih kecil dibandingkan $0,5 \%$, akan tetapi diperoleh nilai yield yang besar. Hal ini menunjukkan bahwa konsentrasi $1 \%$ memiliki efektifitas yang baik untuk waktu reaksi ini. Pada konsentrasi $1,5 \%$ dan 2,0 \% memiliki nilai TOF dan yield yang rendah. Hal ini menunjukkan bahwa pada konsentrasi tersebut kurang efektif terhadap reaksi karena katalis yang digunakan terlalu banyak dan terjadi reaksi penyabunan yang menyebabkan yield biodieselnya kecil. 


\section{- Pengaruh Rasio Minyak:Metanol}

Yield biodiesel yang optimal selain dipengaruhi konsentrasi katalis $\mathrm{KOH}$ juga dipengaruhi oleh rasio berat minyak:metanol. Reaksi transesterifikasi merupakan reaksi kesetimbangan, untuk mendapatkan produk yang banyak maka digunakan alkohol dalam jumlah berlebih agar reaksi bergeser ke produk ( $\mathrm{Fu}$ dkk, 2012). Pada penelitian ini reaksi transterifikasi dilakukan variasi rasio minyak:metanol (1:1, 2:1, 3:1) dengan konsentrasi katalis $1 \%$ berat minyak dan suhu $65^{\circ} \mathrm{C}$. Hasil biodiesel yang diperoleh dengan variasi rasio berat minyak:metanol yaitu berwarna kuning dan jernih.

Tabel 2. Yield dan kandungan metil ester biodiesel minyak kemiri sunan yang diproduksi dengan variasi rasio berat minyak:metanol.

Variasi rasio minyak dengan metanol menghasilkan yield dan jumlah kandungan metil ester yang berbeda. Yield dan kandungan metil ester pada biodiesel dengan variasi rasio minyak dengan metanol

\begin{tabular}{|l|c|c|c|c|c|}
\hline \multirow{2}{*}{ No } & \multirow{2}{*}{$\begin{array}{c}\text { Rasio berat } \\
\text { minyak:metanol }\end{array}$} & \multicolumn{3}{|c|}{ Jenis metil ester (\%) } & \multirow{2}{*}{ Yield (\%) } \\
\cline { 3 - 5 } & & Palmitat & Stearat & Oleat & \\
\hline 1. & $1: 1$ & 28,15 & 16,30 & 55,55 & 96,91 \\
\hline 2. & $2: 1$ & 27,55 & 15,22 & 57,23 & 86,92 \\
\hline 3. & $3: 1$ & 19,55 & 33,96 & 46,49 & 42,33 \\
\hline
\end{tabular}

(Sumber : Olah Data)

Ditunjukkan pada Tabel 2. Jumlah metil ester pada variasi rasio minyak:metanol seluruhnya didominasi oleh metil oleat. Pada rasio minyak:metanol 1:1 memiliki yield biodesel paling optimum 96,91\% dengan kandungan metil oleat besar yaitu 55,55\% dibandingkan dengan metil palmitat 15,30\% dan stearat $28,15 \%$. Berbeda halnya dengan rasio minyak:metanol (2:1) diperoleh yield biodiesel yang kecil yaitu $86,92 \%$ dengan kandungan metil oleat yang besar 57,23\%. Pada rasio minyak:metanol 3:1 diperoleh yield biodiesel terkecil yaitu 47,33\% dengan kandungan metil oleat cukup kecil 46,49\% dibandingkan dengan vaiasi rasio yang lain. 
Nilai yield biodiesel dengan variasi rasio berat minyak:metanol $1: 1 ; 2: 1$; dan $3: 1$ (berat/berat) berturut-turut 96,$91 ; 86,92$ dan 47,33\%. Yield biodiesel optimum diperoleh dari variasi metanol:minyak (1:1) yaitu sebesar $96,91 \%$, hal ini dikarenakan jumlah metanol yang digunakan dalam reaksi berlebih sehingga akan menggeser reaksi ke produk (Dermibas, 2007). Agarwal dkk (2012) melaporkan produksi biodiesel menggunakan katalis KOHdari minyak limbah penggorengan menunjukkan bahwa rasio minyak:metanol sangat berpengaruh pada hasil yield biodiesel. Semakin tinggi rasio minyak:metanol maka yield biodiesel yang dihasilkan juga semakin besar, akan tetapi jika jumlah metanol yang digunakan untuk produksi biodiesel terlalu besar, maka pemisahan gliserol menjadi sulit dan mengakibatkan turunnya nilai yield biodiesel. Penurunan yield biodiesel ditunjukkan dengan rasio berat minyak :alkohol 1,5:1 diperoleh yield biodiesel 98,5\% dan dengan rasio berat minyak :alkohol 1:3,3 diperoleh yield 94,1\% (Wang dkk., 2012). Pada penelitian ini diperoleh rasio berat minyak metanol optimal yaitu pada rasio berat minyak:metanol (1:1), dilihat dari yield yang dihasilkan sebesar $96,91 \%$.

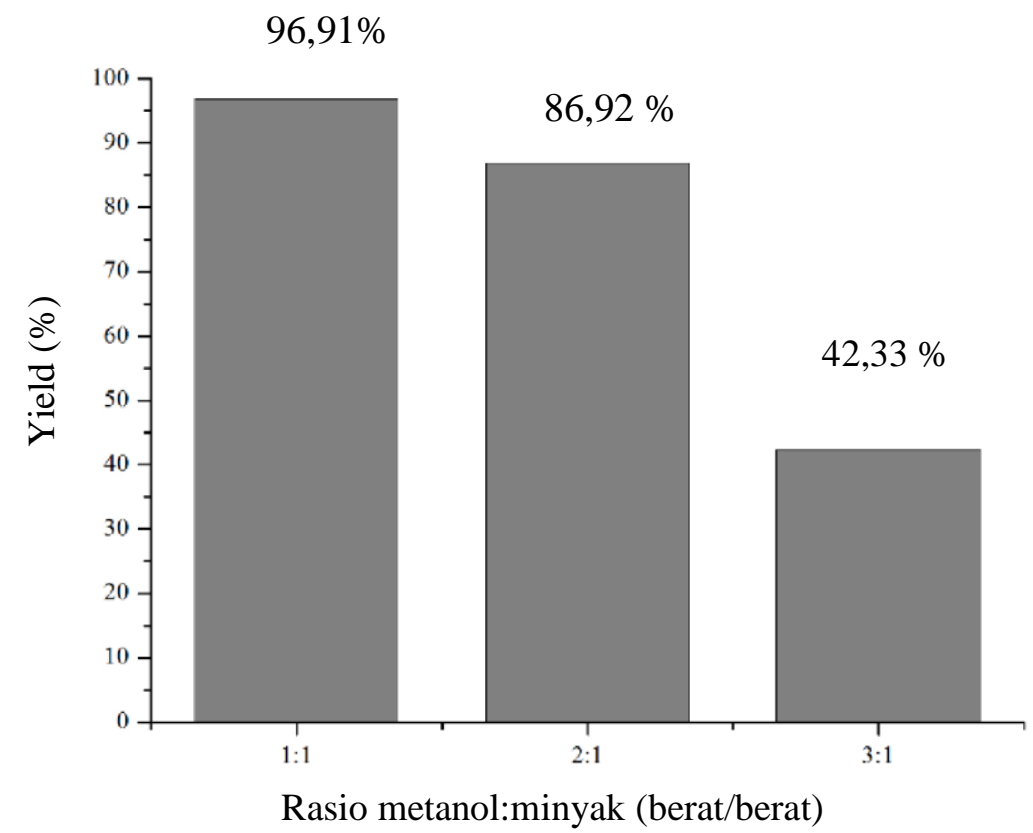

Gambar 4. Pengaruh variasi rasio berat:minyak:metanol $1: 1 ; 2: 1 ; 3: 1$ (berat/berat) dengan yield biodiesel pada reaksi transesterifikasi dengan kondisi konsentrasi katalis $1 \%$ berat minyak dan suhu $65^{0}$ C selama 1 jam.

\section{Karakterisasi}

Karakteristik biodiesel pada kondisi optimum, yaitu biodiesel yang diproduksi dengan menggunakan katalis $\mathrm{KOH} 1 \%$ berat, rasio berat minyak:metanol 1:1 dan suhu reaksi $65{ }_{\circ} \mathrm{C}$ selama 1 jam [19], [20], [21], [22]. Pada kondisi optimum ini diperoleh angka asam $0,55 \mathrm{mgKOH} / \mathrm{gram}$, densitas $0,89 \mathrm{gram} / \mathrm{cm} 3$, viskositas 9,33 cSt, angka setana 63,3 dan residu karbon $0,25 \%$ berat/berat. Nilai karakteristik biodiesel kemiri sunan dengan beberapa variasi kondisi secara umum berada pada rentang angka asam 0,41-0,56 $\mathrm{mgKOH} / \mathrm{gram}$, densitas $0,89-0,91 \mathrm{gram} / \mathrm{cm}_{3}$, viskositas 8,28-12,70 cSt, angka setana 58,2-63,3 dan residu karbon 0,23-0,59\%berat/berat. 


\section{Kesimpulan}

Rekayasa produksi biodiesel dari minyak kemiri sunan (Reutealis trisperma oil) dengan katalis $\mathrm{KOH}$ diperoleh kondisi optimum reaksi transesterifikasi pada suhu $65^{\circ} \mathrm{C}$, konsentrasi katalis $1,0 \%$, rasio berat minyak:metanol 1:1 (berat/berat), selama 1 jam dengan yield 96,91\%. Karakteristik biodiesel tersebut diperoleh angka asam $0,55 \mathrm{mgKOH} / \mathrm{gram}$, densitas $0,89 \mathrm{gram} / \mathrm{cm}_{3}$, viskositas 9,33 cSt, angka setana 63,3 dan residu karbon 0,25 \% berat/berat. Nilai karakteristik biodiesel kemiri sunan dengan beberapa variasi kondisi secara umum berada pada rentang angka asam 0,41-0,56 $\mathrm{mgKOH} / \mathrm{gram}$, densitas 0,89-0,91 $\mathrm{gram} / \mathrm{cm}_{3}$, viskositas 8,28-12,70 cSt, angka setana 58,2-63,3 dan residu karbon 0,23-0,59 \%berat/berat.

Pada penelitian selanjutnya, perlu dilakukan proses pemurnian minyak kemiri sunan sehingga diharapkan dapat diperoleh yield biodiesel yang lebih tinggi dan lebih murni. Selain itu juga perlu dilakukan beberapa upaya untuk menangani karakteristik dari biodiesel kemiri sunan seperti viskositas dan residu karbon agar memasuki rentang standart biodiesel SNI 04-7182 dan ASTM D-6751.

\section{Daftar Pustaka}

[1] D. Huang, H. Zhou, and L. Lin, "Biodiesel: An alternative to conventional fuel," Energy Procedia, vol. 16, no. PART C, pp. 1874-1885, 2012.

[2] S. D. Anggraini, "Rekayasa Produksi Biodiesel Dari Minyak Kemiri Sunan (Reutialis Trisperma Oil) Sebagai Alternatif Bahan Bakar Mesin Diesel," JATI UNIK J. Ilm. Tek. dan Manaj. Ind., vol. 2, no. 1, p. 1, 2019.

[3] X. Zhang, D. J. Zhao, and J. M. Shen, "A synthesis of methodologies and practices for developing driving cycles," Energy Procedia, vol. 16, no. PART C, pp. 1868-1873, 2011.

[4] X. C. Guan, B. Lei, Z. Y. Li, and R. Zhao, "Research on performance high-speed multi-stage cylinder linear induction motor," Energy Procedia, vol. 16, no. PART C, pp. 1904-1912, 2011.

[5] A. Nalgundwar, B. Paul, and S. K. Sharma, "Comparison of performance and emissions characteristics of DI CI engine fueled with dual biodiesel blends of palm and jatropha," Fuel, vol. 173, pp. 172-179, 2016.

[6] M. M. Roy, W. Wang, and J. Bujold, "Biodiesel production and comparison of emissions of a DI diesel engine fueled by biodiesel-diesel and canola oil-diesel blends at high idling operations," Appl. Energy, vol. 106, pp. 198-208, 2013.

[7] S. Goyal, H. A. Ingley, and P. Barooah, "Occupancy-based zone-climate control for energyefficient buildings: Complexity vs. performance," Appl. Energy, vol. 106, pp. 209-221, 2013.

[8] M. M. K. Bhuiya, M. G. Rasul, M. M. K. Khan, N. Ashwath, A. K. Azad, and M. A. Hazrat, "Prospects of 2nd generation biodiesel as a sustainable fuel - Part 2: Properties, performance and emission characteristics," Renew. Sustain. Energy Rev., vol. 55, pp. 1129-1146, 2016.

[9] H. M. Mahmudul, F. Y. Hagos, R. Mamat, A. A. Adam, W. F. W. Ishak, and R. Alenezi, "Production, characterization and performance of biodiesel as an alternative fuel in diesel engines - A review," Renew. Sustain. Energy Rev., vol. 72, pp. 497-509, 2017.

[10] L. Wang, R. Zhang, Z. Xiao, and Y. Xia, "Study on the time decreasing trend model of condenser cleanness coefficient," Energy Procedia, vol. 16, no. PART C, pp. 1860-1867, 2012.

[11] A. K. Agarwal, "Biofuels (alcohols and biodiesel) applications as fuels for internal combustion engines," Prog. Energy Combust. Sci., vol. 33, no. 3, pp. 233-271, 2007.

[12] A. K. Agarwal and L. M. Das, "Biodiesel development and characterization for use as a fuel in 
compression ignition engines," J. Eng. Gas Turbines Power, vol. 123, no. 2, pp. 440-447, 2001.

[13] E. Acar et al., "Development of Stitched, Braided and Woven Composite Structures in the ACT Program and at Langley Research Center (1985 to 1997)," J. Aircr., 2011.

[14] L. Li, J. Wang, Z. Wang, and J. Xiao, "Combustion and emission characteristics of diesel engine fueled with diesel/biodiesel/pentanol fuel blends," Fuel, vol. 156, pp. 211-218, 2015.

[15] R. Oktavian, B. Poerwadi, C. W. K, T. Septiadi, and I. Yuniardi, "Studi Performa Membran Hidrofobik Berbasis Silika dalam Proses Pemurnian Biodiesel," J. Rekayasa Bahan ALam dan Energi Berkelanjutan, vol. 3, no. 1, pp. 20-24, 2019.

[16] Q. Hanifa and N. Hidayati, "Transesterifikasi Minyak Jelantah Menjadi Biodiesel Menggunakan Gelombang Ultrasonik dan Katalis Na 2 O / Fly Ash,” vol. 4, no. April, pp. 1-5, 2019.

[17] Y. Gemy, S. Helianty, and Yusnimar, "PEMBUATAN BIODIESEL DARI SAWIT OFF GRADE DENGAN MENGGUNAKAN KATALIS ZnO KOMERSIAL PADA PROSES TRANSESTERIFIKAS," JOM FTERKNIK, vol. 79, no. 11, pp. 470-471, 2015.

[18] S. Savitri, A. S. Nugraha, and I. Aziz, "Pembuatan Katalis Asam (Ni/ $\gamma-A 12 O 3)$ dan Katalis Basa ( Mg/ $\gamma-\mathrm{Al} 2 \mathrm{O} 3)$ untuk Aplikasi Pembuatan Biodiesel dari Bahan Baku Minyak Jelantah," J. Kim. Val., vol. 2, no. 1, pp. 1-10, 2016.

[19] E. Mulyadi, "Proses Produksi Biodiesel Berbasis Biji Karet," Proses Produksi Biodiesel Berbas. Biji Karet, vol. 5, no. 2, pp. 40-44, 2011.

[20] S. K. Putri et al., "Studi Proses Pembuatan Biodiesel dari Minyak Kelapa (Coconut Oil) dengan Bantuan Gelombang Ultrasonik," Stud. Proses Pembuatan Biodiesel dari Miny. Kelapa (Coconut Oil) dengan Bantu. Gelombang Ultrason., vol. 6, no. 1, pp. 20-25, 2013.

[21] B. D. Argo and Gunarko, “Analisis Energy Produksi Biodiesel,” J. Rekayasa Mesin, vol. 2, no. 1, pp. 39-45, 2011.

[22] F. D. Putri, Z. Helwani, and D. Drastinawati, "Pembuatan Biodiesel dari Minyak Sawit OffGrade Menggunakan Katalis CaO Melalui Proses Dua Tahap," J. Rekayasa Kim. Lingkung., vol. 10 , no. 3, 2015. 